\title{
中空構造栽培槽の立体配置による壁面緑化材としての利用
}

\section{内山知二 ${ }^{*}$ 1)－佐野修司 1）：遠藤常嘉 2）：工藤 渚 2）－山崎敬亮 3) 長崎裕司 3) - 西本登志 4) - 松山貪三 5) - 隅谷智宏 6)}

1）地方独立行政法人大阪府立環境農林水産総合研究所

2) 鳥取大学農学部農学研究科

3）独立行政法人農業・食品産業技術総合研究機構近畿中国四国農業研究センター

4）奈良県農業総合センター

5）大日本プラスチックス株式会社

6）株式会社ヴェイル

摘要 : 中空構造栽培槽は, 垂直方向に多段配置することで壁面を 構成することができるため, 自由度の高い壁面緑化材として利用 できると考えられる。そこで，イチゴやレタスを植栽した栽培槽 を垂直方向に配置して壁面を構成し, 保温材の有無や品種間差に ついて調査した。その結果，寒冷期においても簡易な保温によっ て生育が確保され, 本栽培槽が壁面緑化材として有用であること を示した。

キーワード : 壁面緑化, 可動型植栽, 食用植物, 作業性

\section{1. はじめに}

建築物を緑化するにあたつて, 屋上や外壁面への植栽につ いては栽培槽等の植栽基盤の多様化が求められている 1)。内 山ら 2)は, 軽量であることを特徵とする薄層培地を提案し, また, Yamazaki et al. 5) は農業分野で知見のある蒸発潜熱を 利用した培地冷却技術を開発した。そして内山ら ${ }^{3)}$ は, これ らの両技術を融合した中空構造栽培槽を製作し，植栽位置の 自由度を高められることを示した。また, 内山ら 4) 中, 中空 構造栽培槽には培地内部に大きな空間があるため, この空間 を利用してパイプを通すことができ，専用の部材を使うこと なく空間緑化基盤が構成できることを示した。本報では, 栽 培槽を多段に積層することで壁面を構成した場合のイチゴお よびレタスの生育について調査した。

\section{2. 材料ならびに方法}

\section{1 栽培槽の構成}

供試した中空構造栽培槽の使用部材を示す（表-1）。栽培 用土は園芸用土として一般的なピートモスとバーミキュライ トの混合培土とした。中空構造を保つために，外筒は $2 \mathrm{~mm}$ 目合いのトリカルネットと栽培槽の形状を保つ骨格となる
$40 \mathrm{~mm}$ 目合いのトリカルネットを貼り合わせ, 内筒は防根透 水性シートを巻き付けた $20 \mathrm{~mm}$ 目合いのトリカルネットと した。外筒に内筒を入れ，この間隙に混合培土を入れた。筒 の両端は培土が流出しないようにスポンジで蓋をした。なお, 栽培槽は長さ $1 \mathrm{~m}$ を 1 ユニットとした。

\section{2 栽培槽の配置および植栽}

前述の方法で製作した中空構造栽培槽を作業足場に用いら れる鋼管を支持材として用いて，3ユニットを縦 3 段に積み 重㸚た（図-1）。

表-1 中空構造栽培槽に使用した部材

\begin{tabular}{rcc}
\hline 構 & 成 & 部 材 \\
\hline 外 & 筒 & トリカルネット $(40 \mathrm{~mm}$ 目合い, $2 \mathrm{~mm}$ 目合い $)$ \\
内 & 筒 & トリカルネット $(20 \mathrm{~mm}$ 目合い $)$, 防根シート \\
混合培土 & ピートモス : バーミキュライト $(2: 1)$ \\
側 & スポンジ \\
\hline
\end{tabular}

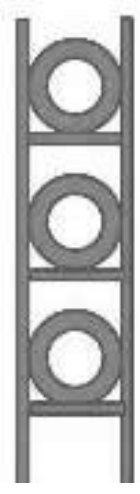

(側面)

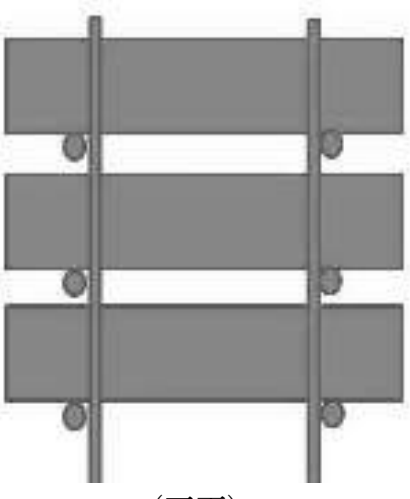

（正面）
図-1 壁面を想定した中空構造栽培槽配置の模式図 
表-2 試験の設定内容

\begin{tabular}{ccccc}
\hline 栽培槽の位置 & 保温被覆材 & イチゴ品種 & レタス品種 \\
\hline 上 段 & 有 & 章姫 & レッドファイア \\
中 段 & 有 & " & フリンジーレッド \\
下 段 & 無 & " & " \\
\hline
\end{tabular}

栽培槽ごとの設定内容を表 -2 に示した。 3 段のうち，上の 2 段は栽培槽の外側を保温被覆材 $(0.1 \mathrm{~mm}$ 厚ポリエチレンシ 一ト）で被覆した。植栽は，イチゴとレタスをそれぞれ設定 した。イチゴはポット苗を，レタスはセル成型苗を用いた。 2 品目とも中空構造栽培槽 1 ユニットにつき, 2 列各 5 か所 に 10 株定植し, 経時的に株径を調査した。イチゴについては, 葉数, 葉色, 果房数も調査した。なお, レタスはポリエチレ ン被覆した上段と中段に別品種を定植し，中断と下段を同一 品種とした。植栽した栽培槽は, 無加温のビニルハウス内に 設置して管理した。

\section{3. 結果および考察}

\section{1 イチゴの生育}

2 月 5 日と 3 月 28 日におけるイチゴの生育状況を写真- 1,2 に示す。また，株径の推移を図-2 に示す。株径は，3 月上旬 までほとんど伸張が見られなかったものの, その後の気温の 上昇にともなって中・下段では，順調に伸張した。

葉数の推移を図-3 に示す。葉数も株径と同様に気温の上昇 にともなって増加し，特に中段で顕著であった。

葉色の推移を図-4 に示す。葉色は，保温した上・中段と， 保温しなかった下段で特徵が見られた。すなわち，低温期に は保温によって養分吸収が順調となり葉色が濃く保たれ, そ の後の温度上昇によって培地中の養分が不足して淡緑化した と考えられた。

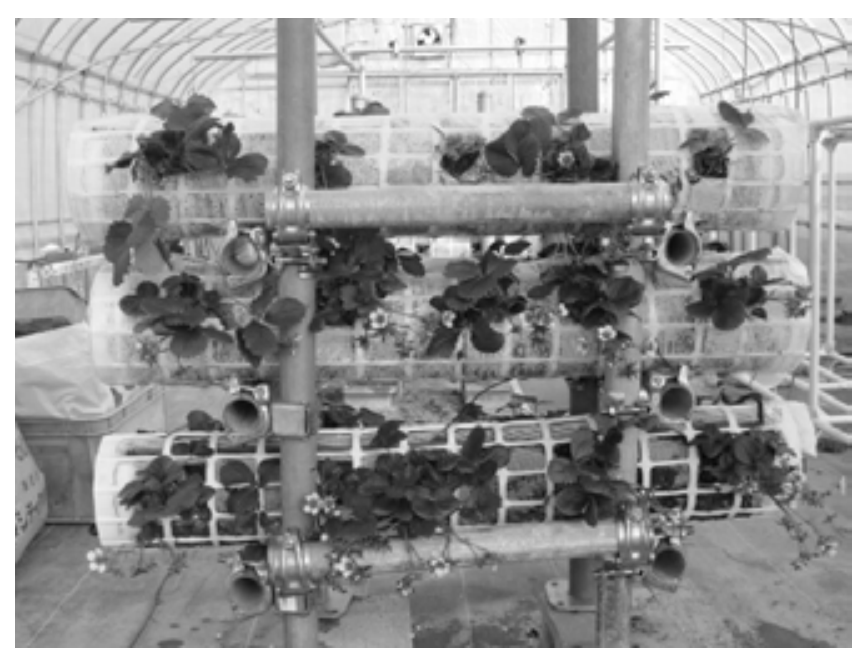

写真-1 イチゴの生育状況（2 月 5 日）

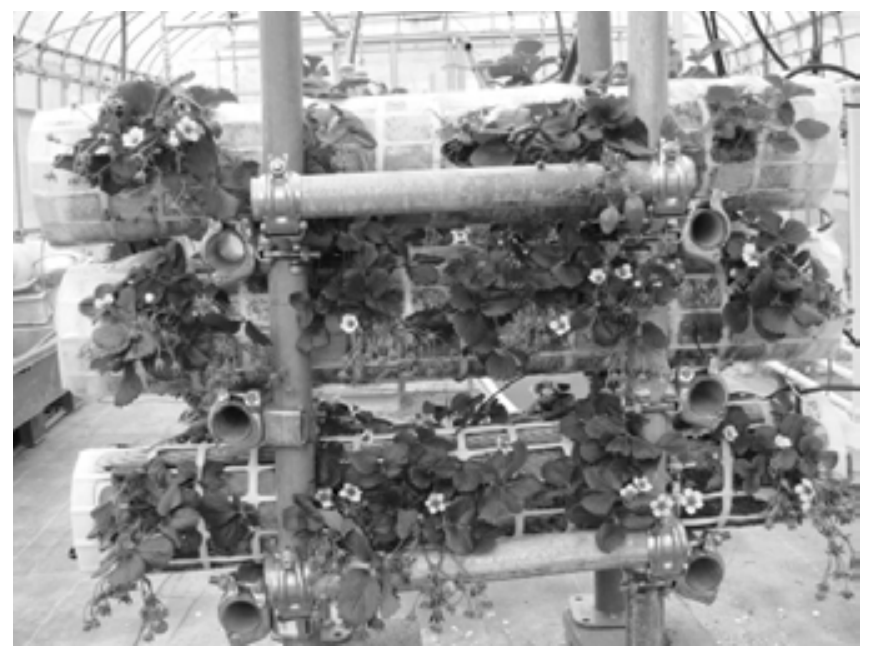

写真-2 イチゴの生育状況（3月 28 日）

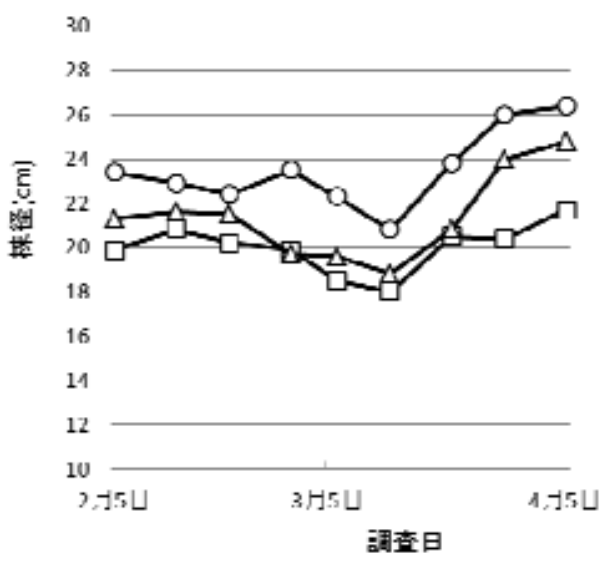

$\square$; 上段， $\bigcirc$; 中段， $\triangle$; 下段

図-2 イチゴの株径の推移

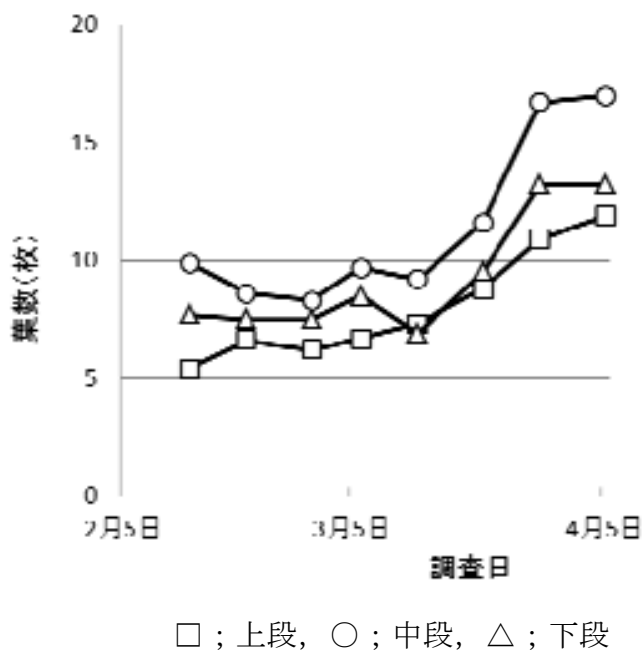

図-3 イチゴの葉数の推移 


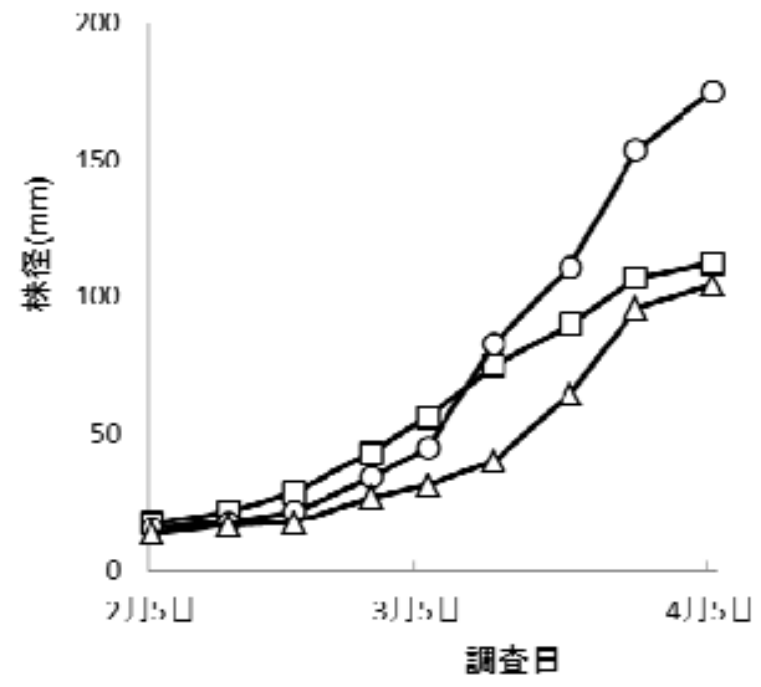

$\square$; 上段， $\bigcirc$; 中段， $\triangle$; 下段

図-4 イチゴの葉色の推移

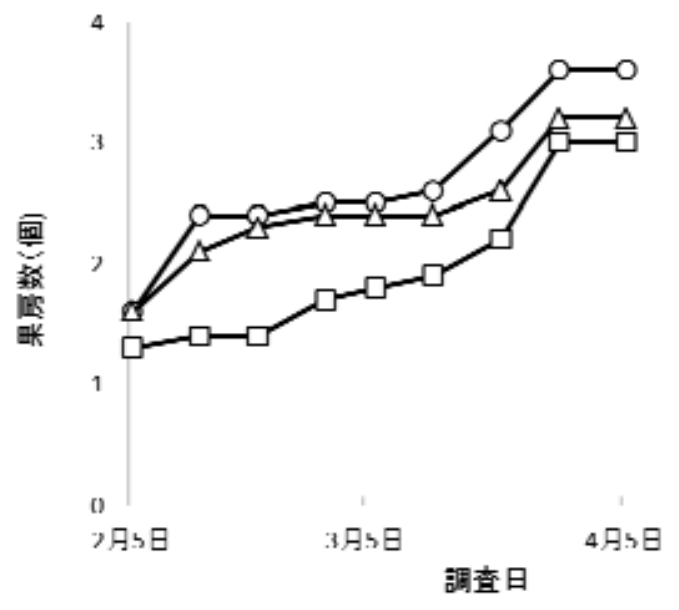

$\square$; 上段， $\bigcirc$; 中段， $\triangle$; 下段

図-5 イチゴの果房数の推移

果房数の推移を図 -5 に示す。果房数は保温の影響は小さ く, 3 月 28 日には着色した果実も得られた。

\section{2 レタスの生育}

レタスの株径の推移を図-6 に示す。また， 2 月 5 日と 3 月 28 日における生育状況を写真- 3,4 に示寸。

レタスは，イチゴと異なり，保温しても品種によって生育 が緩慢であった。しかし，同一品種でも保温しなかった場合， 定植初期に受けた影響が大きく，寒冷期の生育が長期にわた つて抑制され，その後の生育にばらつきが大きくなった。こ のことから，緑化材料として安定した緑化面を構成するため には品種の選定や植栽時期に留意する必要がある。

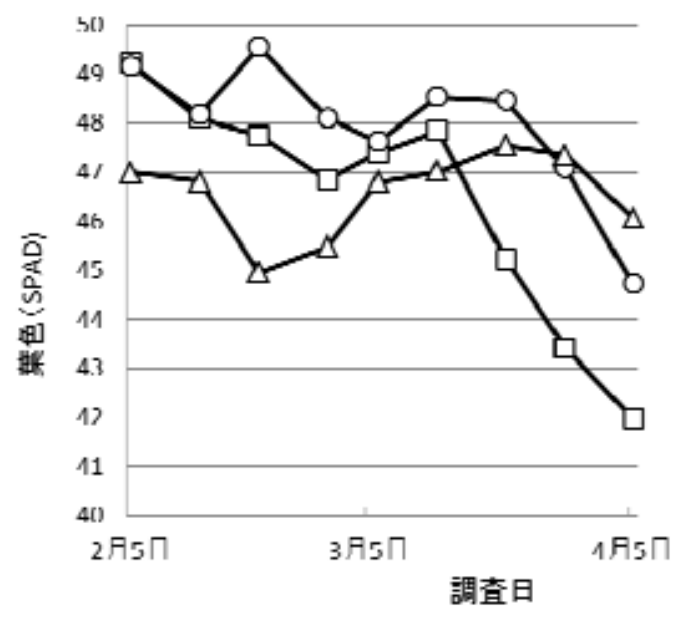

$\square$; 上段， $\bigcirc$; 中段， $\triangle$; 下段

図-6 レタスの株径の推移

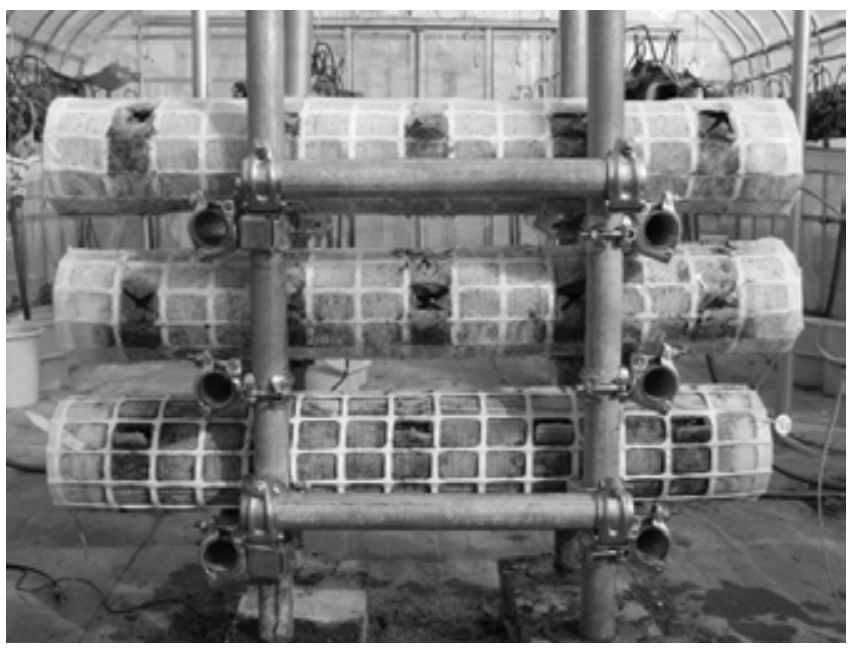

写真-3 レタスの生育状況（2月５日）

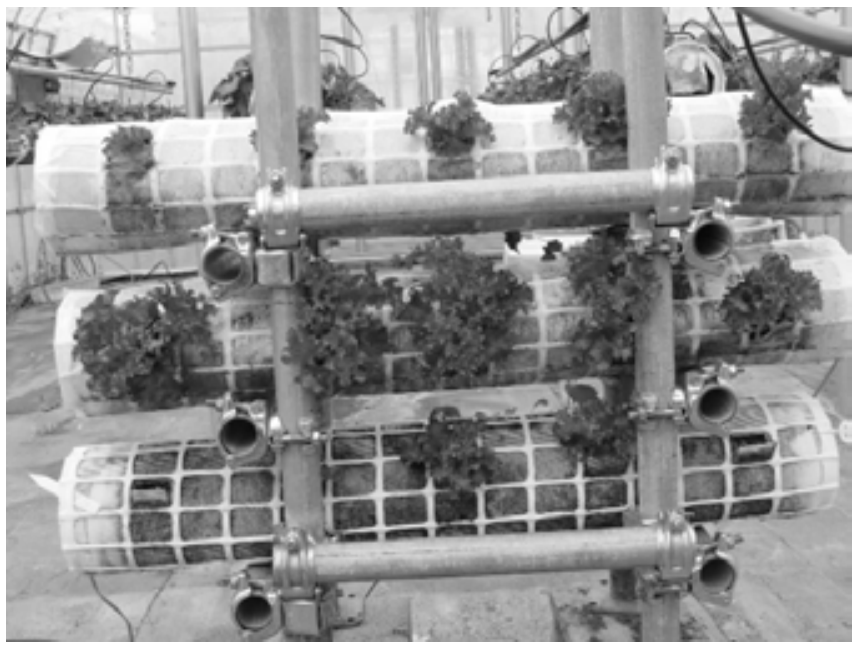

写真-4 レタスの生育状況（下 3 月 28 日） 
以上の結果から, 中空構造栽培槽を壁面形状に配置するこ とで，従来とは異なった壁面緑化材料として活用できること が明らかとなった。

\section{引用文献}

1）辻永岳史・輿水肇（2009）不均一な水分分布を抑制した壁 面緑化基盤構造における粒径構成, 日本緑化工学会誌, 35 (1) : 27-32.

2）内山知二・西本登志 - 山崎敬亮 $\cdot$ 熊倉裕史 - 長崎裕司 $\cdot$ 佐 野修司・遠藤常嘉・隅谷智宏 (2011) 中空構造栽培の空間 緑化基盤としての特性とイチゴおよびレタスの生育, 日本 緑化工学会誌, 37(1) : 163-166.

3）内山知二・豊原憲子・三瀬順三（2005）アスファルト上に
敷設した薄層培地の構成がナデシコ類の生育に及ぼす影 響, 近畿中国四国農業研究, $6: 19-23$.

4）内山知二 ・ 山崎敬亮 - 長崎裕司 - 佐野修司 - 西本登志 - 遠 藤常嘉・工藤 渚・松山眞三・隅谷智宏 (2012) 中空構造 栽培槽の 3 次元移動による栽培植物の光環境への影響, 日 本緑化工学会誌, 38(1): 145-148.

5) Yamazaki,K.,Kumakura,H.,Hamamoto,H.(2009) Shortening of non-harvest period in high bench strawberry forcing culture by a simple control method of medium temperature, Acta Horticulturae , 733-736.

(2013. 6. 20 受理) 